О.М. Полуйко, П.М. Онипченко, О.О. Казіміров, В.П. Невзоров, Ю.І. Тригуб

Харківський національний університет Повітряних Сил ім. І. Кожедуба, Харків

\title{
ВИБІР НАПРЯМКІВ АТАК І ОБҐРУНТУВАННЯ ОПТИМАЛЬНОÏ ПОСЛІДОВНОСТІ ДІЙ ТАКТИЧНИХ ГРУП (ЛІТАКІВ) ТАКТИЧНОÏ АВІАЦІЇ ПРИ НАНЕСЕННІ УДАРУ
}

Вибір найбільш доцільних способів і тактичних прийомів подолання сучасної ППО противника при нанесенні ударів по його наземним об'єктам є актуальним завданням під час бойового застосування авіації в сучасних умовах. У статті, одним із иляхів вирішення даного завдання, пропонується автоматизація розрахунку і вибору найвигіднішого маршруту подолання ППО противника. Це дозволить із урахуванням багатьох факторів, які впливають на ефективність подолання ППО противника, в короткий термін знайти такий варіант польоту літального апарату за марирутом, при якому протидія наземних зенітноракетних комплексів противника буде мінімальною. Використання запропонованої методики дозволить підвищити якість прийняття рішень командирами при відпраџюванні оптимального варіанту дій авіаційних частин (підрозділів) при виконанні бойових завдань.

Ключові слова: ППО противника, автоматизація розрахунків, маршрут польоту, ударна група, спосіб виходу на ичіль.

\section{Вступ}

Постановка проблеми. Досвід локальних війн і операції об’єднаних сил (ООС) свідчить, що на сьогодні велика уваги приділяється посиленню об'єктової протиповітряної оборони (ППО) військ і важливих об'єктів противника, як одного з основного засобів боротьби 3 нашою авіацією, особливо на малих і гранично-малих висотах, в районах їх розташування. Це викликає необхідність удосконалення існуючих способів обгрунтування дій тактичної авіації в районі об'єкту удару.

Одним із шляхів вирішення даного завдання $\epsilon$ автоматизація розрахунку вибору напрямків атак i оптимальної послідовності дій тактичних груп (літаків) тактичної авіації (ТА) при нанесенні удару. Це дозволить із урахуванням багатьох факторів, що впливають на ефективність подолання об'єктового ППО противника, в короткий термін знайти такий варіант послідовності і напрямків атаки літальних апаратів (ЛА) по об’єкту, при якому протидія наземних зенітно-ракетних комплексів (ЗРК) (зенітнострілецьких комплексів (ЗСК)) буде мінімальною. Дане завдання вирішується шляхом визначення оптимальних способів дій ТА в районі об’єктів противника на електронно-обчислювальному пристрої (ЕОП).

Аналіз останніх досліджень і публікацій показує, що вибір напрямків атак і обгрунтування оптимальної послідовності дій тактичних груп (літаків) ТА при нанесенні удару по об'єктах противника частково викладені у [2-4; 9].
В [7] розглянуті питання застосування українських засобів ППО в умовах ООС. В [5; 8] висвітлені питання загального досвіду застосування ПС в OOC.

Методи відпрацювання рішень під час планування бойових дій, а також дослідження бойової ефективності ТА під час авіаційної підтримки СВ були розглянуті в [1].

Однак, обгрунтування оптимального варіанту дій, для виконання бойових завдань підрозділами ТА в районі об'єкту удару, за рахунок мінімізації втрат літаків з застосуванням ЕОП під час планування бойових дій потребує більш досконалої розробки [11-13].

Тобто розробки методики розрахунків параметрів маневру виходу в атаку підрозділів ТА, з урахуванням відомих координат наземних засобів ППО противника, що прикривають об'єкт дій.

Мета статті: розробити методику постановки та розв'язання задачі пошуку оптимальної, за критерієм найменшого математичного очікування числа успішних пусків (вражаючих пострілів) об'єктових засобів ППО противника, послідовності дій і напрямків атак в умовах відомого складу угруповання об’єктових засобів ППО.

\section{Виклад основного матеріалу}

Метою розв'язання даного завдання є одержання кількісних показників для визначення напрямків виходу в атаку за критерієм найменшого математичного очікування числа успішних пусків (вражаючих пострілів) об’єктових засобів ППО (найме- 
ншої імовірності подолання ППО противника, що прикриває об'єкт.

Сутність завдання зводиться до наступного:

- відомі елементарні цілі складного об'єкта, по яких необхідно здійснювати прицілювання, і визначені екіпажі, що виконують атаку;

- відомі координати наземних засобів ППО, що прикривають об'єкт дій;

- для обраних трьох варіантів напрямків виходу в атаку визначаються параметри маневру.

Потрібно визначити:

- імовірність подолання ППО в районі цілі;

- відносний збиток, що наноситься об'єкту удару, 3 урахуванням імовірності подолання об’єктової ППО;

- оптимальний варіант виходу в атаку;

- параметри маневру (оптимальну послідовність дій тактичних груп (літаків).

У процесі розробки завдання було встановлено, що для зручності розв'язання і аналізу одержуваних результатів ऑї доцільно розділити на два блоки. У першому 3 них необхідно визначати оптимальний варіант виходу в атаку, у другому - параметри маневру при його виконанні.

Для визначення ймовірності подолання ППО літаками ударної групи при виконанні першої (другої) атаки використовуються вирази [6]:

$$
\begin{aligned}
& Q_{1}=e^{-\frac{a}{N}}, \\
& Q_{2}=e^{-\frac{a_{2}}{N Q_{1}}} .
\end{aligned}
$$

де $\quad N$-кількість літаків в ударній групі;

$a_{2}$ - математичне очікування числа вражаючих пострілів (успішних пусків) протидіючих засобів ППО противника від моменту застосування зброї в першій атаці до моменту застосування зброї в другий;

$a$ - математичне очікування загального числа вражаючих пострілів (успішних пусків) протидіючих засобів ППО об'єкта до моменту застосування зброї в даній (першій або другій атаці).

Математичне очікування загального числа вражаючих пострілів (успішних пусків) протидіючих засобів ППО об’єкта до моменту застосування зброї в даній (першій або другій атаці) розраховується по формулі:

$$
a=\sum_{i=1}^{n_{3 P K}} a_{i}\left(1-P_{n_{i}}\right),
$$

де $n_{3 Р к}-$ кількість протидіючих при виконанні першої (другої) атаки ЗРК (ЗСК) противника;

$a_{i}$ - математичне очікування числа успішних пусків (вражаючих пострілів) $i$-го протидіючого ЗРК (ЗСK);
$P_{n_{i}}-$ імовірність придушення $i$-го ЗРК (ЗСК) противника.

Збиток, що наноситься $j$-й цілі об'єкта рівний [4]:

$$
U=1-\prod_{N=1}^{K} a_{i}\left(1-Q_{1} P_{n o p_{j}}\right),
$$

де $\quad N$-кількість літаків, що атакують $j$-ту ціль.

При розробці завдання прийняті наступні обмеження й допущення:

- не враховуються рельєф місцевості й метеорологічні умови;

- не враховується фактор раптовості;

- маневрування літаків при визначенні напрямків виходу в атаку розглядається тільки в горизонтальній площині.

Крім того при визначенні напрямків атаки прийняті наступні умови:

- напрямки атак по цілям, ефективність поразки яких змінюється значно менше зі зміною напрямку заходу, можуть відхилятися від оптимального на $20^{\circ}-30^{\circ}$ убік, що забезпечує менший розкид у напрямках атак або можливість нанесення одночасних ударів по більшому числу цілей складного об'єкта;

- напрямки атак по цілям, ефективність поразки яких значно змінюється зі зміною заходу, повинні бути або оптимальними або близькими до них;

- напрямки атак по цілям, ефективність поразки яких не залежить від напрямку заходу (атаки), не повинні виходити із сектору напрямків атак по інших цілях і забезпечити простоту маневру;

- положення точки розходження по цілям складного об'єкта повинно забезпечити прицільне застосування засобів поразки й простоту маневру для виходу на напрямок атаки [4].

Частота розв'язання даного завдання залежить від кількості складних об'єктів, призначених підрозділу протягом доби і може скласти до 10 - 12 раз за добу. Тривалість підготовки і їі розв'язання не повинна перевищувати трьох хвилин.

Результати розв'язання завдання повинні безпосередньо видаватися на засоби відображення інформації.

Аналіз бойових дій тактичної авіації показав, що вихід на ціль, першу та другу атаки доцільно здійснювати 3 різних напрямків 3 мінімально можливими тимчасовими інтервалами між ударними групами (літаками) [10]. Це змушує противника розосередити зусилля об'єктових засобів ППО, що збільшує ймовірність ії подолання.

Таким чином підвищується ефективність вогневого впливу по цілям.

У деяких випадках найбільш доцільним способом виходу бомбардувальників на ціль для вико- 
нання першої атаки з різних напрямків є здійснення всією ударною групою польоту до цілі в єдиному бойовому порядку по одному маршруту до пункту бойової розбіжності з наступним розмиканням на відповідні підгрупи (літаки) шляхом виконання розрахункового маневру.

Один з варіантів такого способу представлений на рис. 1 .

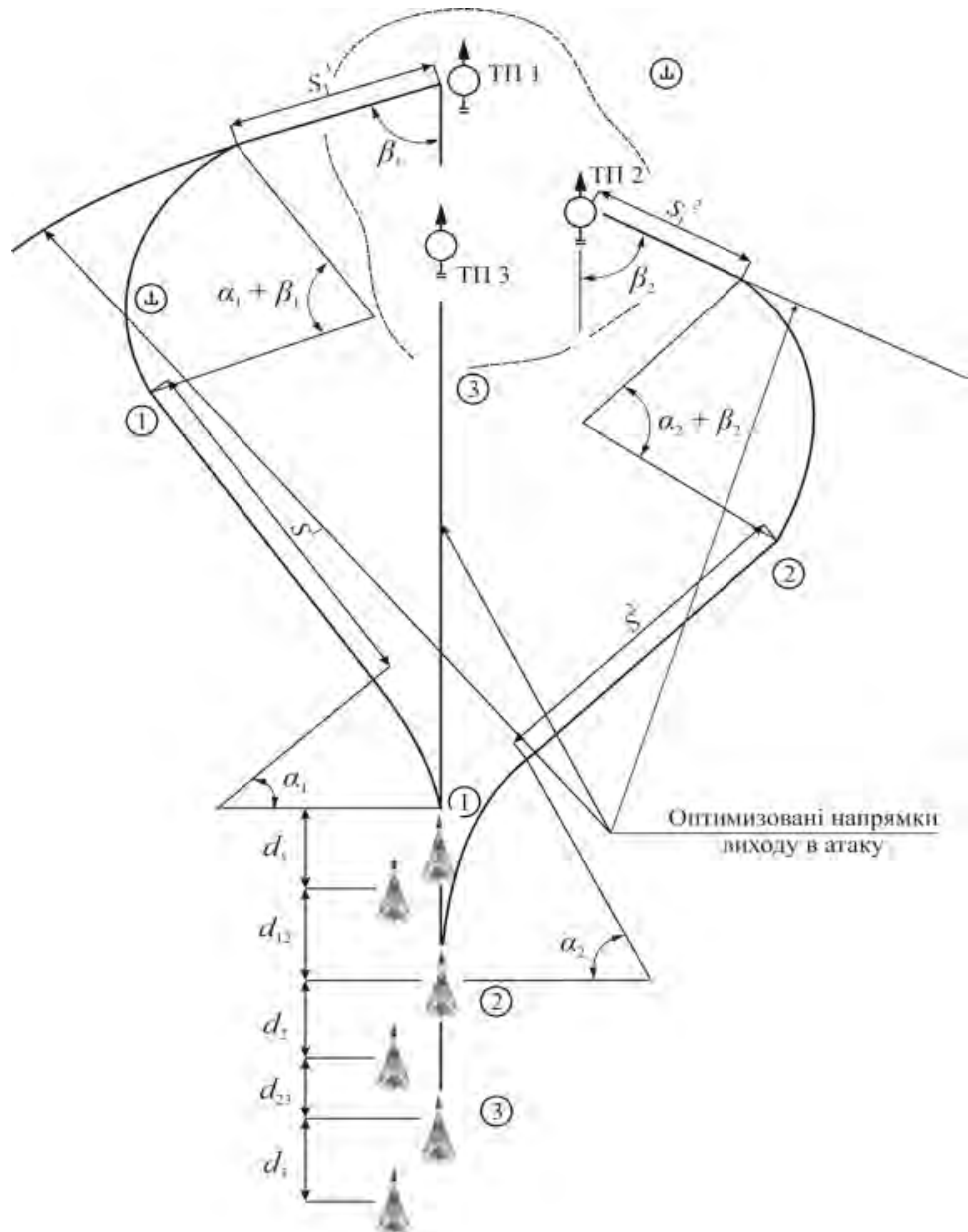

Рис. 1. Вихід бомбардувальників

на ціль для виконання першої атаки (варіант)

Вихід на ціль $з$ різних напрямків дозволить варіювати параметрами маневру, для розрахунків яких використовуються відповідні формульні залежності [4].

Дальність до цілі на початку виконання маневру розраховується за допомогою виразку:

$$
D_{K}=S \cdot \cos \beta+\frac{V^{2}}{9,81} \cdot \operatorname{ctg}(\sin \beta+2 \sin \alpha)+5 \cos \alpha,
$$

де

$$
S=\frac{S_{1} \sin \beta-\frac{V^{2}}{9,81} \operatorname{ctg} \gamma(1+\cos \beta-2 \cos \alpha)}{\sin \alpha} .
$$

Час виконання маневру розраховується за формулою:

$$
\Delta T_{\text {манк }}=0,00178 \cdot V \cdot \operatorname{ctgj}(\beta+2 \alpha) \cdot t_{S}+\frac{S}{V}-\frac{D_{K}}{V},
$$

де $t_{S}=\frac{S}{V}$.
Якщо маневр виконується без прямолінійної ділянки польоту від першого до початку другого розвороту, то кут першого одворота розраховується за формулою:

$$
\cos \alpha=0,5+\frac{\cos \beta}{2}-4,95 \frac{S_{1} \sin \beta \operatorname{tg} \gamma}{V^{2}} .
$$

Часовий інтервал $\Delta t_{y \kappa} \delta$ між початком нанесення удару $\delta$-тою й $k$-тою ударними групами (літаками) розраховується за допомогою виразку:

$$
\Delta t_{\text {укठ }}=\Delta T_{\text {манк }}-\frac{d k-d k_{\delta}}{V},
$$

де $d k-$ глибина бойового порядку $k$-тої групи:

$d k_{\delta}$ - дистанція між $k$-тою й $\delta$-тою групами (літаками).

Значення $d k \mathrm{i} d k_{\delta}$ при розв'язанні визначеного завдання вводяться в діалоговому режимі.

Алгоритм блоку по визначенню параметрів маневру представлений на рис. 2. 


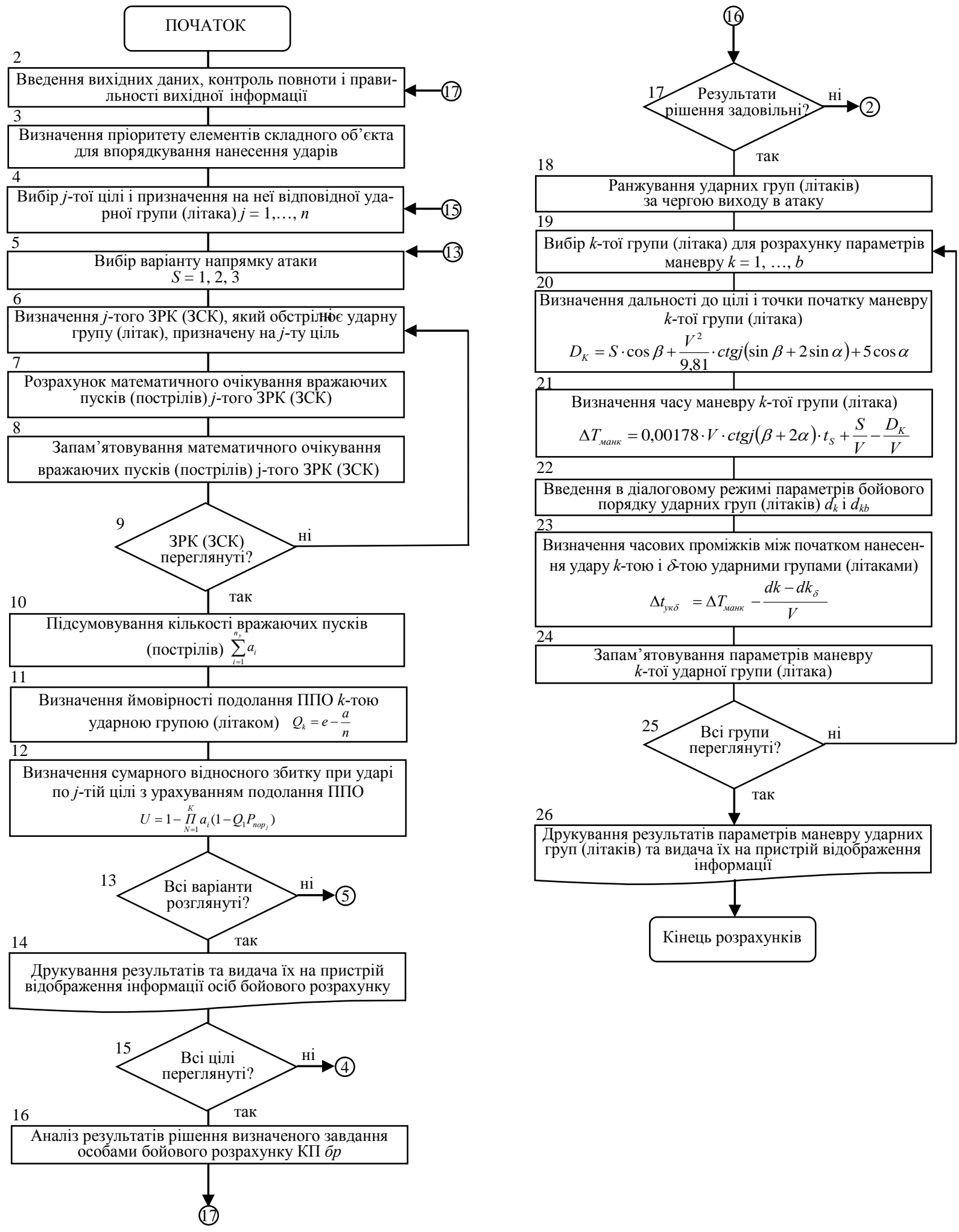

Рис. 2. Алгоритм блоку по визначенню параметрів маневру

\section{Висновки}

Проведене в статті дослідження дозволило сформулювати пропозиції щодо оптимізації маршруту подолання ППО противника підрозділами ТА. Запропоновані модель і алгоритм рішення задачі дозволяють на етапі планування бойових дій особами бойової обслуги частин (підрозділів) ТА, суттєво підвищити якість прийняття рішення, скоротити термін на підготовку до бойових дій в умовах дефіциту часу та підвищити ефективність виконання бойових завдань в умовах ведення бойових дій. 
Використання запропонованої методики дозволить виробити оптимальний варіант бойового польоту до об'єкту дій і назад, а також автоматизувати процес прийняття рішення при підготовці до бойових дій.

\section{Список літератури}

1. Срмошин М.О. Боротьба в повітрі / М.О. Єрмошин, В.М. Федай. - Х.: ХВУ, 2004. - 381 с.

2. Кушнір O.I. Аналіз впливу «гібридної» війни на розвиток автоматизованої системи управління авіацією та ППО Збройних Сил України / О.І. Кушнір, О.П. Давикоза, Ю.Ф. Кучеренко // Наука і техніка Повітряних Сил Збройних Сил України. - 2017. - № 2(27). - С. 116-120. https://doi.org/10.30748/nitps.2017.27.22.

3. Худов Г.В. Методика синтезу раціональної структури підсистеми розвідки системи протиповітряної оборони 3 використанням генетичного алгоритму / Г.В. Худов, І.А. Таран // Наука і техніка Повітряних Сил Збройних Сил України. - 2016. - № 2(23). - С. 25-31.

4. Полуйко О.М. Оптимальний розподіл сил і засобів авіаційної бригади по заданих об'єктах у груповому удаpi / О.М. Полуйко, П.М. Онипченко // Наука і техніка Повітряних Сил Збройних Сил України. - 2016. - № 1(22). - С. 18-20.

5. Алімпієв А.М. Особливості гібридної війни РФ проти України. Досвід, що отриманий Повітряними Силами Збройних Сил України / А.М. Алімпієв, Г.В. Пєвцов // Наука і техніка Повітряних Сил Збройних Сил України. - 2017. № 2(27). - C. 19-25. https://doi.org/10.30748/nitps.2017.27.03.

6. Нізієнко Б.І. Аспекти удосконалення системи управління протиповітряною обороною України / Б.І. Нізієнко, С.А. Юхновський, С.А. Макаров // Наука і техніка Повітряних Сил Збройних Сил України. - 2017. - № 1(26). - С. 17-20. https://doi.org/10.30748/nitps.2017.26.03.

7. Особливості застосування підрозділів ЗРВ у ситуації ескалації воєнного конфлікту на території держави / С.П. Ярош, В.В. Воронін, М.О. Срмошин та ін. - Х.: ХУПС, 2015. - 140 с.

8. Досвід та особливості застосування авіації Повітряних Сил Збройних Сил України у ході АТО / А.М. Алімпієв, М.І. Коморний, О.К. Шейгас та ін.; під заг. кер. А.М. Алімпієва. - Х.: ХУПС, 2016. - 67 с.

9. Полуйко О.М. Вибір точок прицілювання по елементарним цілям складного (групового) об'єкту / О.М. Полуйко, П.М. Онипченко // Системи озброєння і військова техніка. - 2017. - № 2(50). - С. 22-25.

10. Тактика бомбардувальної авіації. Ч. 1. Основи тактики бомбардувальної авіації / О.Б. Котов, О.І. Лагузов, С.А. Калкаманов, П.М. Онипченко. - Х.: ХНУПС, 2018. - 164 с.

11. Харитонов О.Л. До питання розвитку теорії створення системи зенітного ракетного вогню (теорії і практики підготовки та ведення протиповітряного бою) частинами і підрозділами ЗРВ / О.Л. Харитонов, А.О. Харитонов // Наука і техніка Повітряних Сил Збройних Сил України. - 2014. - № 4(17). - С. 38-40.

12. Оцінювання ефективності бойових дій зенітних ракетних підрозділів, озброєних різнотипними зенітними ракетними (ракетно-гарматними) комплексами на основі імітаційного моделювання / С.П. Ярош, К.В. Закутін, В.В. Шулежко, В.В. Воронін, А.М. Савельєв, А.Ф. Макаров // Системи обробки інформації. - 2015. - № 8(133). - С. 60-65.

13 Методика оптимізації маршруту подолання ППО противника підрозділами тактичної авіації / О.М. Полуйко, П.М. Онипченко, О.В. Тимошенко, В.Я. Корецький // Системи озброєння і військова техніка. - 2018. - № 4(56). C. 48-53. https://doi.org/10.30748/soivt.2018.56.07.

14. Казіміров О.О. Аналіз способів і прийомів застосування тактичної авіації в локальних війнах та збройних конфліктах / О.О. Казіміров, Р.В. Нєвзоров, В.В. Шмаков // Системи озброєння і військова техніка. - 2009. - № 2(18). - С. 11-13.

\section{References}

1. Yermoshin, M.O. and Feday, V.M. (2004), “Borotba v povitri” [Fighting in the air], KhVU, Kharkiv, $381 \mathrm{p}$.

2. Kushnir, O.I., Davikoza, O.P. and Kucherenko, Yu.F. (2017), “Analiz vplyvu "gibridnoi” viiny na rozvytok avtomatyzovanoi systemy upravlinja aviatsieju ta PPO Zbroinykh Syl Ukrainy” [Analysis of the influence of the "hybrid” war on the development of the automated control system of aviation and air defense of the Armed Forces of Ukraine], Science and Technology of the Air Forces of Ukraine, No. 2(27), pp. 116-120. https://doi.org/10.30748/nitps.2017.27.22.

3. Hudov, G.V. and Taran, I.A. (2016), "Metodyka syntezu ratsionalnoi struktury pidsystemy rozvidky systemy protypovitrjanoi oborony z vykorystanjam genetychnogo algorytmu” [Method of synthesis of the rational structure of the intelligence subsystem air defense system with the use of the genetic algorithm], Science and Technology of the Air Forces of Ukraine, No. 2(23), pp. 25-31.

4. Polujko, O.M. and Onypchenko, P.M. (2016), “Optymalny rozpodil syl i zasobiv aviatsinoi brygady po zadanykh obiektakh u grupovomu udari” [Optimal distribution of forces and means of aviation brigade on given objects in a group blow], Science and Technology of the Air Forces of Ukraine, No. 1(22), pp. 18-20.

5. Alimpiev, A.M. and Pevtsov, G.V. (2017), “Osoblyvosti gibridnoi viiny RF proty Ukrainy. Dosvid, scho otrymanyi Povitrjanymy Sylamy Zbroinykh Syl Ukrainy” [Features of the hybrid war against the Russian Federation. Experience gained by the Air Forces of the Armed Forces of Ukraine], Science and Technology of the Air Forces of Ukraine, No. 2(27), pp. 19-25. https://doi.org/10.30748/nitps.2017.27.03.

6. Nizienko, B.I., Yukhnovsky, S.A. and Makarov, S.A. (2017), “Aspekty udoskonalenja systrmy upravlinja pronypovitrjanoju oboronoju Ukrainy” [Aspects of improvement of the air defense defense control system of Ukraine], Science and Technology of the Air Forces of Ukraine, No. 1(26), pp. 17-20. https://doi.org/10.30748/nitps.2017.26.03. 
7. Yarosh, S.P., Voronin, V.V. and Yermoshyn, M.O. (2015), “Osoblyvosti zastosuvanja pidrozdiliv ZRV u sytuatsii eskalatsii voenogo konfliktu na teritorii dergavy" [Features of the use of AAF units in the situation of escalation of the military conflict in the territory of the state], KhUPS, Kharkiv, $140 \mathrm{p}$.

8. Alimpiev, A.M., Komorny, M.I. and Shaigas, O.K. (2016), “Dosvid ta osoblyvosti zastosuvania aviatsii Povitrianykh Syl Zbroinykh Syl Ukrainy u khodi ATO" [Experience and peculiarities of the use of aviation of the Air Forces of the Armed Forces of Ukraine during ATO], KhUPS, Kharkiv, $67 \mathrm{p}$.

9. Pouljko, O.M. and Onypchenko, P.M. (2017), "Vybir tochok prytsiliuvania po elementarnym tsiliam skladnogo (grupovogo) obiektu" [Selection of points of sighting for the elementary goals of a complex (group) object], Systems of Arms and Military Equipment, No. 2(50), pp. 22-25.

10. Kotov, O.B., Laguzov, O.I., Kalkamanov, S.A. and Onypchenko, P.M. (2018), “Taktyka bombarduvalnoi aviatsii. Ch. 1. Osnovy taktyky bombarduvalnoi aviatsii” [Tactics of bomber aviation. Part 1. Basics of Bombing Aviation Tactics], KhNUPS, Kharkiv, $164 \mathrm{p}$.

11. Kharitonov, O.L. and Kharitonov, A.O. (2014), "Do pytania rozvytku teorii stvorenia systemy zenitnogo raketnogo vogniu (teorii i praktyky pidgotovky ta vedenia protypovitrianogo boiu) chastynamy i pidrozdilamy ZRV” [On the development of the theory of the creation of a system of anti-aircraft missile fire (the theory and practice of antiaircraft combat preparation and conduct) by parts and units of AAF], Science and Technology of the Air Forces of Ukraine, No. 4(17), pp. 38-40.

12. Yarosh, S.P., Zakutin, K.V., Shulyhko, V.V., Voronin, V.V., Saveliev, A.M. and Makarov, A.F. (2015), “Otsiniuvania efektyvnosti boiovykh dii zenitnykh raketnykh pidrozdiliv, ozbroenykh riznotypnymy zenitnymy raketnymy (raketnogarmatnymy) kompleksamy na osnovi imitatsiinoho modeliuvania” [Evaluation of the effectiveness of combat operations of antiaircraft missile units armed with various anti-aircraft missile (missile-gun) complexes based on simulation], Information Processing Systems, No. 8(133), pp. 60-65.

13. Poluiko, O.M., Onypchenko, P.M., Tymoshenko, O.V. and Koretskyi, V.Ya. (2018), "Metodyka optymizatsii marshrutu podolannia PPO protyvnyka pidrozdilamy TA" [Technique for optimizing the route of enemy air defense overcoming by TA units], Systems of Arms and Military Equipment, No. 4(56), pp. 48-53. https://doi.org/10.30748/soivt.2018.56.07.

14 Kazimirov, O.O., Nievzorov, R.V. and Shmakov, V.V. (2009), “Analiz sposobiv i pryiomiv zastosuvannia taktychnoi aviatsii v lokalnykh viinakh ta zbroinykh konfliktakh” [Analysis of methods and techniques of tactical aviation in local wars and armed conflicts], Systems of Arms and Military Equipment, No. 2(18), pp. 11-13.

\section{Відомості про авторів:}

\section{Полуйко Олександр Миколайович} кандидат військових наук доцент професор кафедри Харківського національного університету Повітряних Сил ім. І. Кожедуба, Харків, Україна https://orcid.org/0000-0002-1560-9906

\section{Онипченко Павло Миколайович} кандидат педагогічних наук доцент завідувач кафедри Харківського національного університету Повітряних Сил ім. І. Кожедуба, Харків, Україна https://orcid.org/0000-0003-4497-327X

Казіміров Олександр Олексійович кандидат військових наук доцент професор кафедри Харківського національного університету Повітряних Сил ім. І. Кожедуба, Харків, Україна https://orcid.org/0000-0002-7509-5118

\section{Information about the authors:}

\section{Oleksandr Polujko}

Candidate of Military Sciences Associate Professor

Professor of Department

of Ivan Kozhedub Kharkiv

National Air Force University,

Kharkiv, Ukraine

https://orcid.org/0000-0002-1560-9906

Pavlo Onypchenko

Candidate of Pedagogical Sciences Associate Professor

Head of Department

of Ivan Kozhedub Kharkiv

National Air Force University,

Kharkiv, Ukraine

https://orcid.org/0000-0003-4497-327X

\section{Oleksandr Kazimirov}

Candidate of Military Sciences Associate Professor

Professor of Department

of Ivan Kozhedub Kharkiv

National Air Force University,

Kharkiv, Ukraine

https://orcid.org/0000-0002-7509-5118 
Невзоров Віктор Петрович

викладач кафедри Харківського

національного університету

Повітряних Сил ім. І. Кожедуба,

Харків, Україна

https://orcid.org/0000-0002-3355-4451

\section{Тригуб Юрій Ігорович}

викладач

Харківського національного університету

Повітряних Сил ім. І. Кожедуба,

Харків, Україна

https://orcid.org/0000-0001-6785-0286

\author{
Viktor Nevzorov \\ Instructor of Department \\ of Ivan Kozhedub Kharkiv \\ National Air Force University, \\ Kharkiv, Ukraine \\ https://orcid.org/0000-0002-3355-4451
}

\author{
Yurii Trigub \\ Instructor \\ of Ivan Kozhedub \\ Kharkiv National Air Force University, \\ Kharkiv, Ukraine \\ https://orcid.org/0000-0001-6785-0286
}

\section{ВЫБОР НАПРАВЛЕНИЙ АТАК И ОБОСНОВАНИЕ ОПТИМАЛЬНОЙ ПОСЛЕДОВАТЕЛЬНОСТИ ДЕЙСТВИЙ ТАКТИЧЕСКИХ ГРУПП (САМОЛЕТОВ) ТАКТИЧЕСКОЙ АВИАЦИИ ПРИ НАНЕСЕНИИ УДАРА}

А.Н. Полуйко, П.Н. Онипченко, А.А. Казимиров, В.П. Невзоров, Ю.И. Тригуб

Выбор наиболее иелесообразных способов и тактических приемов преодоления современной ПВО противника при нанесении ударов по его наземным объектам является актуальной задачей во время боевого применения авиации в современных условиях. В статье, одним из путей решения данной задачи, предлагается автоматизация расчета и выбора наиболее выгодного марирута преодоления ПВО противника. Это позволит с учетом многих факторов, влияюших на эффективность преодоления ПВО противника, в короткий срок найти такой вариант полета летательного аппарата по маршруту, при котором противодействие наземных зенитно-ракетных комплексов противника будет минимальным. Отмечается, что иелью решения данной задачи является поиск оптимального по критерию минимума успешных пусков (поражающих выстрелов) маршрута полета в условиях известной группировки средств ПвО противника. Сущчность решения задачи заключается в том, что на основании исходной информации электронно-вычислительное устройство осуществляет поиск маршрута, представленного прямолинейными участками путем последовательного перехода от опорной (начальной) траектории к оптимальной за конечное число шагов. При этом критерием является минимальное суммарное количество успешных пусков (поражающих выстрелов). Конечным результатом является оптимальные координаты поворотных пунктов маршрута и высота полета на участках маршрута с точки зрения эффективного преодоления ПВО противника. Использование предложенной методики позволит повысить качество принятия решений командирами при отработке оптимального варианта действий авиационных частей (подразделений) при выполнении боевых задач.

Ключевые слова: ПВО противника, автоматизачия расчетов, маршрут полета, ударная группа, способ выхода на иель

\section{CHOICE OF DIRECTIONS OF ATTACKS \\ AND JUSTIFICATION OF THE OPTIMAL SEQUENCE OF ACTIONS OF TACTICAL GROUPS (AIRCRAFT) TACTICAL AVIATION AT IMPACT}

O. Poluiko, P. Onypchenko, O. Kazimirov, V. Nevzorov, Yu. Trigub

The choice of the most appropriate methods and tactics of overcoming the enemy's modern air defense while striking at their ground targets is an urgent task during the combat use of aviation in modern conditions. In the article, one of the ways to solve this problem is the automation of calculation and selection of the most profitable route for overcoming the enemy's air defense. This will allow taking into account many factors affecting the effectiveness of overcoming the enemy's air defense, in a short time to find such an option for the flight of an aircraft along a route in which opposition of the ground anti-aircraft missile systems of the enemy will be minimal. It is noted that the goal of solving this problem is to find the optimal flight criterion according to the criterion of the minimum of successful launches (striking shots) in the conditions of a well-known grouping of enemy air defense equipment. The essence of the solution of the problem lies in the fact that, based on the initial information, the electronic computing device searches for a route represented by straight sections by successively switching from the reference (initial) trajectory to the optimal one in a finite number of steps. In this case, the minimum total number of successful launches (striking shots) is the criterion. The end result is the optimal coordinates of the turning points of the route and the flight altitude on the route sections from the point of view of effectively overcoming the enemy air defense. The proposed models and an algorithm for solving the problem will contribute, at the stage of planning combat operations by combatants of tactical aviation units (subunits), to significantly improve the quality of decision-making, reduce the time for preparation for military operations in the conditions of time pressure, and increase the efficiency of combat missions in combat military operations. Using this technique will allow you to develop the best option for a combat flight to the target and vice versa, as well as automate the decision-making process in preparation for combat operations.

Keywords: enemy air defense, automation of calculations, flight route, strike group, method of reaching the target. 